\title{
Studies on development of low sodium chicken strips
}

\author{
ANIL DANGE, SARVADNYA, Y.P. GADEKAR AND R.D. KOKANE
}

\begin{abstract}
A process for rehydratable shelf stable low sodium chicken strips (LSCS) from spent hen meat to use in soups, curries, stews etc. was developed. On the basis of preliminary trials of various salt replacers and their effects on physio-chemical attributes three treatments were finalised, viz., spent hen meat strips treated with $\mathrm{NaCl}$ and $\mathrm{KCl}$ in 50:50 ( $\left.\mathrm{T}_{1}\right)$, spent hen meat strips treated with $\mathrm{NaCl}_{\text {and }} \mathrm{MgCl}_{2}$ in $60: 40$ ( $\mathrm{T}_{2}$ ), spent hen meat strips treated with $\mathrm{NaCl}$ and $\mathrm{CaCl}_{2}$ in $70: 30\left(\mathrm{~T}_{3}\right)$, were compared with spent hen meat strips treated with $\mathrm{NaCl} 100$ per cent as control to check the influence of these treatments on sensory attributes. The LSCS were analyzed for proximate composition and sodium on $0^{\text {th }}$ day, change in $\mathrm{pH}$, water activity, tyrosine value and TBARS value as well as microbial parameters during storage at ambient temperature were also performed at 10 days interval for total period of 30 days. All the treated and control exhibited similar amount of protein (79.49-81.83 $\%$ ) and fat (3.36-3.83\%). A progressive increased was noticed during storage study in the water activity, $\mathrm{pH}$, TBARS value, tyrosine value and total plate count with advancement of storage period. In sensory aspects, LSCS treated with $\mathrm{NaCl}: \mathrm{KCl}\left(\mathrm{T}_{1}\right)$ was significantly $(\mathrm{P}<0.01)$ superior over the other two treatments when compare with control. Low sodium chicken strips (LSCS) could be successfully manufactured by replacing 50 per cent $\mathrm{NaCl}$ with $\mathrm{KCl}$.
\end{abstract}

KeY WORDS : $\mathrm{NaCl}, \mathrm{KCl}, \mathrm{MgCl}_{2}, \mathrm{CaCl}_{2}, \mathrm{TBARS}, \mathrm{pH}$

How TO CITE THIS PAPER : Dange, Anil, Sarvadnya, Gadekar, Y.P. and Kokane, R.D. (2014). Studies on development of low sodium chicken strips. Res. J. Animal Hus. \& Dairy Sci., 5(2) : 51-61.

Address for correspondence :

Anil Dange, Department of Livestock Products Technology, Bombay Veterinary College (BVC), Parel, MUMBAI (M.S.) INDIA

Email : dranilnd14@gmail.com

Associated Authors':

Sarvadnya and R.D. Kokane, Department of Livestock Products Technology, Bombay Veterinary College (BVC), Parel, MUMBAI (M.S.) INDIA

Y.P. Gadekar, Central Sheep and Wool Research Institute, Avikanagar, MALPURA (RAJASTHAN) INDIA 